\title{
ANALISIS POTENSI HKI HASIL PENELITIAN DOSEN UNIVERSITAS NEGERI YOGYAKARTA SELAMA KURUN WAKTU 2009-2011
}

\author{
Wawan S. Suherman, Sri Atun, dan Darmono \\ Pusdi PHP \& HKI LPPM Universitas Negeri Yogyakarta \\ Email:ws_suherman@yahoo.com
}

\begin{abstract}
Abstrak: Analisis Potensi HKI Hasil Penelitian Dosen Universitas Negeri Yogyakarta Selama Kurun Waktu 2009-2011. Tujuan penelitian ini adalah untuk menganalisis potensi HKI dan peningkatan perolehan HKI dari hasil penilitian dosen dalam kurun waktu 2009-2011. Sampel penelitian diambil secara purposif random sampling. Metode pengambilan data dilakukan dengan metode dokumentasi, wawancara, pengiriman angket ke dosen yang melakukan penelitian periode tahun 2009-2011, dan pemberian pelatihan atau workshop kepada para dosen yang memiliki hasil penelitian yang berpotensi HKI. Instrumen yang digunakan dalam penelitian ini meliputi cek lis untuk analisis tingkat kebaruan informasi yang terdapat dalam abstrak hasil penelitian dosen yang dibandingkan data informasi HKI. Disamping itu juga digunakan angket untuk menjaring semua informasi tentang profil penelitian dosen UNY tahun 2009-2011. Dari hasil penelitian ini dapat disimpulkan bahwa potensi HKI dari hasil-hasil penilitian dosen dalam kurun waktu 2009-2011, sebanyak 40 judul atau 18,89\%. Beberapa hasil penelitian dosen UNY belum di HKI kan karena berbagai alasan, yaitu belum tau cara mendaftarkan HKI, belum bisa membuat draft HKI, maupun biaya pendaftaran dan pemeliharaan HKI yang mahal.
\end{abstract}

Kata kunci: Analisis potensi HKI dan hasil penelitian.

\begin{abstract}
An Analysis of The Potency of Intellectual Property of Research Result of Yogyakarta State University Lecturer from 2009 until 2011. The purpose of this study was to analyze the potential and to increase of the acquisition of Intellectual property rights (IPR) from the results of researches in the 2009-2011period. The sample of the research was taken with consideration of research purposively random sampling. Method of data collection was done by the documentation, interviews, sending questionnaires to researches who conducted the research in 20092011period, and the provision of training or workshop for the lecture that have the research potential IPR. The instrument used in this study includes a check list for the analysis of the level of novelty the information contained in the abstract results compared to IPR information data. Besides, it also used a questionnaire to capture all the information about result of research profile lecture in 2009-2011period. From these results it can be concluded that the potential of the IPR results of researches in 2009-2011 period, a total of 40 titles or $18.89 \%$. Some result of researches from UNY have not IPR for a variety of reasons, which do not know how to register IPR, have not been able to make the draft of IPR, and the cost of registration and maintenance of IPR are expensive.
\end{abstract}

Keywords: Analysis of potential IPR and research results.

\section{PENDAHULUAN}

Penelitian sebagai salah satu pilar tridharma selain pendidikan dan pengabdian masyarakat, memiliki peran sentral dalam upaya mewujudkan visi UNY. Secara tegas dikemukakan bahwa salah satu fungsi UNY adalah menyelenggarakan dan mengembangkan penelitian dalam rangka pengembangan ilmu pengetahuan, teknologi, seni, dan olahraga. Dengan demikian, kegiatan penelitian perlu diselenggarakan untuk menemukan, mengembangkan, dan menyebar- 
luaskan ilmu pengetahuan, teknologi, seni, dan olahraga, yang menyejahterakan individu dan masyarakat, mendukung pembangunan daerah dan nasional, serta berkontribusi pada pemecahan masalah global.

Ditinjau dari jumlah dana yang terserap dan jumlah kegiatan penelitian, sebanyak lebih dari 500 judul kegiatan dalam waktu tiga tahun terakhir yang telah dilakukan oleh para dosen UNY tersebut, mestinya sudah banyak hasil-hasil penelitian yang diperoleh selama kurun waktu tersebut. Namun demikian dari data yang ada di LPPM, selama rentang dua tahun 2008-2009 publikasi ilmiah yang baru dilaporkan sebanyak 7 publikasi ilmiah tingkat internasional dan 87 tingkat nasional terakreditasi. Sedangkan yang lainnya masih berupa artikel yang disampaikan dalam forum pertemuan ilmiah di tingkat nasional maupun internasional. Luaran dalam bentuk Hak atas Kekayaan Intelektual (HKI), kategori hak cipta, desain produk industri dan perlindungan varietas tanaman juga telah dihasilkan meski jumlahnya masih sangat terbatas, dalam kurun tiga tahun hanya ada 8 judul yang didaftarkan hak patennya. Untuk mengoptimalkan pemanfaatan hasil-hasil penelitian yang telah dilakukan oleh dosen UNY perlu dilakukan analisis potensi HKI dari hasil-hasil penelitian dosen UNY selama kurun waktu tertentu (2009-2011). Dari hasil penelitian tersebut dapat digunakan untuk merumuskan kebijakan maupun program penelitian yang harusnya dilaksanakan di LPPM UNY di masa mendatang, sehingga hasil penelitian para dosen dapat menghasilkan temuantemuan baru yang dapat dipatenkan.

Berdasarkan uraian di atas dapat dirumuskan permasalahan dalam penelitian ini yaitu: (1) Seberapa besar hasil penelitian yang dilakukan oleh dosen dalam kurun waktu tahun 2009-2011 yang berpotensi untuk di-HKI-kan?, (2) Apa kendala bagi para peneliti dalam mendapatkan HKI dari hasil penelitian yang dilakukan untuk kurun waktu tahun 2009-2011?, dan (3) Bagaimanakah upaya yang perlu dilakukan dalam meningkatkan perolehan HKI dari hasil penilitian dosen UNY dalam kurun waktu tahun 2009-2011?

Terdapat dua tujuan dalam penelitian ini yaitu: (1) untuk mengetahui potensi HKI dari hasil-hasil penelitian yang dilakukan dosen dalam kurun waktu 2009-2011, dan (2) sebagai upaya untuk meningkatkan perolehan HKI dari hasil-hasil penelitian dosen UNY. Sedangkan manfaat yang dapat diperoleh dari penelitian ini adalah sebagai masukan dalam merumuskan kebijakan maupun program penelitian yang harusnya dilaksanakan di LPPM UNY di masa mendatang, sehingga hasil penelitian para dosen UNY dapat menghasilkan temuan baru yang dapat dipatenkan.

Sebagai bagian dari Lembaga Pendidik Tenaga Kependidikan (LPTK), Universitas Negeri Yogyakarta semakin memantapkan dirinya untuk menjadi universitas kependidikan kelas dunia (world class university) yang berlandaskan ketaqwaan, kemandirian dan kecendekiaan. Hal ini selaras dengan rumusan tujuan pendidikan nasional yang tertuang dalam Undang-undang Nomor 20 Tahun 2003 tentang Sistem Pendidikan Nasional yang menyatakan bahwa tujuan pendidikan nasional adalah berkembangnya potensi peserta didik agar menjadi manusia yang beriman dan bertakwa kepada Tuhan Yang Maha Esa, berakhlak mulia, sehat, berilmu, cakap, kreatif, mandiri, serta menjadi warga negara yang demokratis dan bertanggung jawab (RIP UNY, 2011).

Kegiatan dan proses belajar mengajar di UNY didukung oleh 1.047 orang tenaga akademik dengan kualifikasi jenjang pendidikan sebagai berikut: SI sebanyak 139 orang $(17,06 \%)$, S2 sebanyak 740 orang $(70,54 \%)$, dan S3 sebanyak 130 orang $(12,39 \%)$. Dari sisi jenis kelamin, 657 orang $(62,63 \%)$ pria dan 392 orang $(37,37 \%)$ wanita. Berdasarkan komposisi tersebut dapat pula dinyatakan bahwa sebanyak 82,93\% dosen bergelar S2 ke atas. Komposisi ini terus bergeser sehingga dosen bergelar S1 makin sedikit. Jumlah guru besar mencapai 48 orang $(4,58 \%)$ (www. uny.ac.id). 
Penelitian sebagai salah satu pilar tridharma selain pendidikan dan pengabdian masyarakat, memiliki peran sentral dalam upaya mewujudkan visi UNY. Secara tegas dikemukakan bahwa salah satu fungsi UNY adalah menyelenggarakan dan mengembangkan penelitian dalam rangka pengembangan ilmu pengetahuan, teknologi, seni, dan olahraga. Dengan demikian, kegiatan penelitian perlu diselenggarakan untuk menemukan, mengembangkan, dan menyebarluaskan ilmu pengetahuan, teknologi, seni, dan/atau olahraga, yang menyejahterakan individu dan masyarakat, mendukung pembangunan daerah dan nasional, serta berkontribusi pada pemecahan masalah global. Aktivitas penelitian dosen UNY baik dengan menggunakan dana DIPA maupun dana eksternal baik dari DP2M, Ristek, Pemda, LIPI, maupun yang lainnya telah menunjukkan peningkatan dari tahun ke tahun (RIP UNY, 2011).

Indikator kinerja utama penelitian (IKUP) ditentukan oleh luaran atau pemanfatan hasil-hasil penelitian. Terdapat sembilan jenis luaran penelitian yang selama ini menjadi pijakan aktivitas penelitian dosen, yaitu publikasi ilmiah, sebagai pemakalah dalam pertemuan ilmiah sebagai pemakalah utama (Keynote speaker), HKI, teknologi tepat guna, desain model, dan buku ajar. Dari data yang ada di LPPM UNY tahun 2011 (RIP UNY, 2011), publikasi ilmiah selama rentang dua tahun 2008-2009 terdapat 7 publikasi ilmiah tingkat internasional dan 87 tingkat nasional terakreditasi, publikasi tingkat lokal sebanyak 183 buah. Selain itu, luaran sebagai pemakalah dalam forum pertemuan ilmiah merupakan luaran kedua yang paling banyak dihasilkan. Untuk jenis Hak atas Kekayaan Intelektual (HKI), hanya ada 8 judul HKI yang didaftarkan, sedangkan laporan penelitian yang belum dipublikasikan sebanyak 648 buah.

Hak Kekayaan Intelektual (HKI) adalah hak eksklusif yang diberikan suatu peraturan kepada seseorang atau sekelompok orang atas karya ciptanya. Secara sederhana HKI mencakup Hak Cipta, Hak Paten dan
Hak Merk. Namun jika dilihat lebih rinci HKI merupakan bagian dari benda, yaitu benda tidak berwujud (benda imateriil). Hak Atas Kekayaan Intelektual (HKI) termasuk dalam bagian hak atas benda tak berwujud (seperti Paten, merek, dan hak cipta). Hak Atas Kekayaan Intelektual sifatnya dapat berupa informasi, ilmu pengetahuan, teknologi, seni, sastra, maupun keterampilan (Asep Herman Suyanto, 2005).

Berdasarkan Undang-undang Nomor 14 Tahun 2001 (Ristek, 2011), paten adalah hak eksklusif yang diberikan oleh Negara kepada Inventor atas hasil invensinya di bidang teknologi, yang untuk selama waktu tertentu melaksanakan sendiri invensinya tersebut atau memberikan persetujuannya kepada pihak lain untuk melaksanakannya (Pasal 1 Ayat 1). Hak khusus yang diberikan negara kepada penemu atas hasil penemuannya di bidang teknologi, untuk selama waktu tertentu melaksanakan sendiri penemuannya tersebut atau memberikan persetujuan kepada orang lain untuk melaksanakannya (Pasal 1 Undang-undang Paten). Paten diberikan dalam ruang lingkup bidang teknologi, yaitu ilmu pengetahuan yang diterapkan dalam proses industri. Di samping paten, dikenal pula paten sederhana (utility models) yang hampir sama dengan paten, tetapi memiliki syarat-syarat perlindungan yang lebih sederhana. Paten dan paten sederhana di Indonesia diatur dalam Undang-undang Paten (UUP).

Setidaknya ada beberapa keuntungan dalam penegakan $\mathrm{HKI}$, yang dapat berpengaruh terhadap pengembangan ilmu pengetahuan dan teknologi di Indonesia. Seperti adanya perlindungan karya tradisional bangsa Indonesia, mencegah pencurian karya lokal yang umumnya masuk kategori paten sederhana dan penemuan-penemuan baru. Adanya masukan pendapatan untuk para penemu/ pencipta. Meningkatkan intensif untuk terus berkarya bagi penemu paten, baik yang dari kalangan pemerintah maupun yang swasta dan agar orang lain terangsang untuk dapat lebih lanjut mengembangkannya lagi. Di samping itu, sistem HKI menunjang 
Tabel 1. Beberapa Situs Alamat Informasi Paten di Dunia

\begin{tabular}{ll}
\multicolumn{1}{c}{ Alamat } & \multicolumn{1}{c}{ Pemilik } \\
\hline http://www.delphion.com & Thomson Group \\
http://ep.espacenet.com & European Patent Office \\
http://www.uspto.gov/patft/index.html & US Patent Office \\
http://www.cambiaip.org & Cambia-Biotech (Australia) \\
http://www.wipo.int/ipdl/en/search/pct & World Intellectual Property Organization WIPO) \\
\hline
\end{tabular}

diadakannya sistem dokumentasi yang baik atas segala bentuk kreativitas manusia sehingga kemungkinan dihasilkannya teknologi atau hasil karya lainnya yang sama dapat dihindarkan/dicegah. Dengan dukungan dokumentasi yang baik tersebut, diharapkan masyarakat dapat memanfaatkannya dengan maksimal untuk keperluan hidupnya atau mengembangkannya lebih lanjut untuk memberikan nilai tambah yang lebih tinggi lagi. Meningkatkan pemahaman hukum HKI pada aparat hukum dan masyarakat. Achmad Zen Umar Purba (2001), menandaskan pentingnya pembudayaan HKI dalam masyarakat. Masyarakat harus menyadari bahwa HKI merupakan aset yang secara hukum berada dalam kewenangan penuh pemiliknya. Temuan yang sudah dijamin dengan HKI dalam bentuk paten atau hak cipta-tidak bisa diklaim lagi oleh pihak lain (Suryomurcito, 2003).

\section{METODE}

Desain penelitian ini adalah diskriptif atau eksploratif, untuk menggali data sesuai apa adanya. Populasi penelitian ini adalah hasil-hasil penelitian dosen UNY periode tahun 2009-2011, sedangkan sampel penelitian hasil penelitian yang berpotensi HKI periode tahun 2009-2011 yang diambil secara purposif dengan pertimbangan penelitian yangdijadikan sampel dipilih yang dananya lebih dari dua puluh juta rupiah. Metode pengambilan data dilakukan dengan metode dokumentasi, wawancara, pengiriman angket ke para dosen yang melakukan penelitian periode tahun 2009-2011, dan pemberian pelatihan atau workshop kepada para dosen yang memiliki hasil penelitian yang berpotensi HKI.
Instrumen yang digunakan dalam penelitian ini meliputi cek lis untuk analisis tingkat kebaruan (novelity) informasi yang terdapat dalam abstrak hasil penelitian dosen yang dibandingkan data informasi paten dapat dilihat pada Tabel 1.

Di samping itu, juga digunakan angket untuk menjaring semua informasi tentang profil penelitian dosen UNY tahun 20092011, profil pemanfaatan hasil-hasil penelitian yang telah dilakukan. Butir pertanyaan dalam angket dan hasil pengumpulan datanya sebagaimana yang disajikan dalam Tabel 2.

\section{HASIL DAN PEMBAHASAN}

Lembaga Penelitian dan Pengabdian kepada Masyarakat Universitas Negeri Yogyakarta (LPPM UNY) memiliki peneliti dan pelaksana pengabdian yang setiap tahunnya menghasilkan karya-karya penelitian dan PPM yang berpotensi paten dan perlu mendapatkan perlindungan atas kekayaan intelektual yang dihasilkan. Para peneliti dan pengabdi di lingkungan LPPM UNY tersebut telah menghasilkan karya penelitian dan PPM yang banyak jumlahnya. Dari jumlah yang banyak tersebut beberapa karya memiliki potensi untuk memperoleh HKI, namun belum teridentifikasi dengan jelas karena keterbatasan tenaga dan dana. Oleh karenanya, hasil penelitian ini merupakan jawaban dari permasalahan tersebut.

Rendahnya persentase perolehan perlindungan Hak Paten dan HKI di UNY ini disebabkan oleh beberapa hal, yang antara lain: (1) minimnya kesadaran peneliti dan pengabdi akan perlindungan HKI, (2) keterbatasan dana untuk pengurusan perolehan HKI, dan (3) tidak tersedianya dana untuk 
Tabel 2. Kisi-kisi dan Hasil Analisis Data Potensi Hasil Penelitian Dosen UNY Kurun Waktu Tahun 2009-2011 untuk Di-HKI-kan

\begin{tabular}{|c|c|c|c|}
\hline No. & Butir Pertanyaan & Jumlah & $\begin{array}{l}\text { Persentase } \\
\quad(\%)\end{array}$ \\
\hline \multirow[t]{4}{*}{1} & Penelitian yang sudah mendapat HKI & & \\
\hline & A. Sudah & 0 & 0,00 \\
\hline & B. Belum & 18 & 100,00 \\
\hline & Jumlah & 18 & 100,00 \\
\hline \multirow[t]{13}{*}{2} & Alasan-alasan & & \\
\hline & a. Belum tahu cara pendaftaran HKI & 11 & 28,21 \\
\hline & b. Belum paham cara menyusun dokumen paten & 8 & 20,51 \\
\hline & c. Hasil penelitian belum layak di-HKI-kan & 8 & 20,51 \\
\hline & d. Tidak ada hasil / inovasi baru yang diperoleh & 1 & 2,56 \\
\hline & e. Biaya pendaftaran/ pengurusan $\mathrm{HKI} /$ paten terlalu mahal & 3 & 7,69 \\
\hline & f. Malas kalau harus mengurus sendiri & 3 & 7,69 \\
\hline & g. Menurut saya HKI/ Paten tidak Penting & 0 & 0,00 \\
\hline & h. Belum tahu cara pendaftaran HKI & 0 & 0,00 \\
\hline & i. Belum ada kesempatan & 1 & 2,56 \\
\hline & j. Penelitian masih dalam tahap awal & 3 & 7,69 \\
\hline & k. Pengurusan lama & 1 & 2,56 \\
\hline & Jumlah & 52 & 100,00 \\
\hline \multirow[t]{4}{*}{4} & Manfaat kegiatan workshop/pelatihan HKI di LPPM & & \\
\hline & a. Bermanfaat & 18 & 100,00 \\
\hline & b. Tidak & 0 & 0,00 \\
\hline & Jumlah & 18 & 100,00 \\
\hline \multirow[t]{13}{*}{5} & Saran dan masukan untuk LPPM dalam peningkatan perolehan & & \\
\hline & HKI/paten hasil penelitian dosen/ civitas akademika UNY & & \\
\hline & a. Workshop diadakan secara periodik & 6 & 28,57 \\
\hline & b. Peserta tidak hanya dosen tetapi juga mhs & 2 & 9,52 \\
\hline & $\begin{array}{l}\text { c. LPPM memfasilitasi penyusunan dokumen dan } \\
\text { pendaftaran HKI }\end{array}$ & 1 & 4,76 \\
\hline & d. Ada skim khusus penelitian yang dapat dipatenkan & 1 & 4,76 \\
\hline & $\begin{array}{l}\text { e. Ada pembicara dari ilmu sosial/ekonomi yang sudah } \\
\text { mendapat paten }\end{array}$ & 1 & 4,76 \\
\hline & f. LPPM perlu membuat edaran/ brosur kegiatan & 2 & 9,52 \\
\hline & g. Disediakan dana untuk pendaftaran/pengurusan & 4 & 19,05 \\
\hline & h. Disediakan award/ hadiah yang mendapat paten & 1 & 4,76 \\
\hline & i. Ada contoh proposal & 2 & 9,52 \\
\hline & j. Sentra HKI lebih proaktif & 1 & 4,76 \\
\hline & Jumlah & 21 & 100,00 \\
\hline
\end{tabular}

perawatan HKI yang telah memperoleh sertifikat. Berdasarkan hasil penelitian yang telah dilakukan oleh para dosen UNY yang terunggah dalam sipenonline LPPM UNY tahun 2012 terdapat sebanyak 859 judul penelitian dengan rincian berasal dari fakultas: FBS sebanyak 150 judul; FE sebanyak 94 judul; FIK sebanyak 151 judul; FIP sebanyak 173 judul; FISE sebanyak 127 judul; FMIPA sebanyak 164 judul. Sumber dana penelitian tersebut berasal dari Direktorat Penelitian dan Pengabdian kepada Masyarakat (Ditlitabmas) Ditjen Dikti Kemendikbud dengan skim penelitian hibah bersaing, fundamental, rapid, stranas, DIPA UNY baik unggulan universitas maupun dari DIPA masing-masing fakultas. Sampel penelitian yang dipilih sebanyak 213 judul. 
Selanjutnya dilakukan analisis kebaruan atau novelity dari penelitian tersebut berdasarkan data informasi paten yang terdapat pada beberapa situs online. Dari data tersebut dapat dipilih 40 judul hasil penelitian. Data tersebut menunjukkan bahwa hasil penelitian dosen UNY pada kurun waktu 2009 - 2011 yang memiliki potensi HKI sebanyak 18,9\%. Namun demikian, untuk dapat didaftarkan HKI-nya perlu analisis lebih lanjut. Selanjutnya para peneliti diundang untuk mengikuti kegiatan workshop informasi HKI dan penyusunan draft paten. Dari 40 peneliti tersebut yang dapat hadir sebanyak 18 orang. Kedelapanbelas orang peneliti yang hadir tersebut diminta untuk mengisi angket dengan hasil analisis seperti yang tercantum dalam Tabel 2.

Ditinjau dari jumlah dana penelitian yang terserap di LPPM UNY dibandingkan dengan jumlah perolehan perlindungan Hak Paten dan HKI para dosen UNY menunjukkan perbandingan yang tidak sebanding (sangat sedikit). Hal ini disebabkan oleh adanya beberapa hal, yaitu: (1) minimnya kesadaran peneliti dan pengabdi akan perlindungan HKI atas karyanya, dan (2) keterbatasan dana untuk pengurusan perolehan HKI, dan (3) tidak tersedianya biaya perawatan untuk HKI yang telah memperoleh sertifikat.

Kegiatan workshop sosialisasi HKI yang diselenggarakan oleh di Pusat Penerapan Hasil Penelitian dan Perlindungan Hak Kekayaan Intelektual (Pusdi PHP \& HKI) secara rutin dilaksanakan satu kali dalam setiap tahun, namun belum efektif dan belum diikuti secara merata oleh kalangan civitas akademika di setia fakultas yang ada di UNY. Hal ini terbukti dengan jawaban responden hasil penelitian dari para peneliti dan pengabdi yang mendapatkan hibah penelitian tahun 2009-2011 menunjukkan bahwa masih lebih dari $80 \%$ peneliti belum mengetahui prosedur pendaftaran paten dan bangaimana membuat draft paten. Selanjutnya dari hasil workshop yang dilakukan oleh Pusdi PHP \& HKI untuk tahun 2012 dapat diperoleh satu penelitian yang didaftarkan patennya. Di masa mendatang kegiatan yang ada di
Pusdi PHP \& HKI perlu lebih diintensifkan, sehingga semakin banyak temuan-temuan baru yang dapat didaftarkan HKI-nya.

Berbagai kegiatan yang relevan dalam rangka untuk meningkatkan jumlah karya para civitas adademika UNY termasuk di dalamnya hasil penelitian, PPM, dan PKM adalah sebagai berikut.

1. Identifikasi hasil penelitian dan PPM yang berpotensi untuk proses hak paten dan kepemilikan HKI secara terusmenerus.

Kegiatan ini dilaksanakan untuk mengindentifikasi karya-karya penelitian dan PPM khususnya karya yang memiliki potensi Paten dan perlindungan HKI. Hasil identifikasi berupa database hasil penelitian/ PPM/ karya yang berpotensi untuk Paten/HKI.

2. Sosialisai HKI kepada seluruh civitas akademika UNY

Kegiatan sosialisai HKI bertujuan untuk memberikan pemahaman tentang arti penting perlindungan hak kekayaan intelektual hasil-hasil penelitian/PPM atau karya non penelitian/ PPM yang berpotensi HKI, sasaran kegiatan adalah seluruh civitas akademika Universitas Negeri Yogyakarta dan masyarakat luar kampus .

3. Penyusunan Panduan Perolehan Hak Paten/ HKI

Kegiatan ini bertujuan memberikan petunjuk secara tertulis dalam bentuk buku panduan yang berkaitan dengan pemahaman dan proses pengurusan berbagai macam perlindungan $\mathrm{HKI}$.

4. Workshop Drafting Paten/ Penulisan Deskripsi Paten

Tujuan dari kegiatan ini adalah untuk memberikan pengetahuan kepada para peneliti/ pelaksana PPM atau pemilik karya yang akan mendaftarkan hasil penelitian/ PPM/ karyanya untuk mendapat perlindungan Hak Paten.

5. Pengurusan Proses Pendaftaran Hak Paten dan Kepemilikan HKI

Kegiatan ini direncanakan untuk membantu proses pendaftaran Paten/ HKI di 
Dirjen HKI, termasuk didalamnya prosedur pengisian form pendaftaran.

6. Peningkatan Kemampuan Sumber Daya Pengelola Sentra HKI

Untuk meningkatkan kemampuan Sumber daya pengelola sentra HKI perlu diikutkan dalam pelatihan-pelatihan Telusur Paten dengan perangkat software terbaru, penulisan deskripsi paten, dan pelatihan aspek-aspek hukum yang berkaitan HKI.

Semua bentuk kegiatan di atas dalam rangka untuk merespon WIPO yang menginformasikan bahwa terdapat dua kategori sebuah karya yang dapat diraih oleh penemunya terkait dengan masalah HKI ini, yaitu: (1) hak cipta dan hak-hak terkait (copy right and related rights) dan (2) hak milik perindustrian (industrial property). Hak cipta (copy right) di dalamnya melindungi karya-karya cipta dalam bidang ilmu pengetahuan, sastra dan seni (seperti: novel, puisi, sandiwara, film, ciptaan musik, lukisan, gambar, fotografi, ukiran, dan karyakarya arsitektur). Sedangkan, hak milik perindustrian (industrial property), misalnya hak atas merek (trade marks), termasuk merek jasa, hak desain industri (industrial designs), hak paten (patents), dan rahasia dagang (undisclosed information, including trade secrets).

\section{SIMPULAN}

Berdasarkan analisis data dan pembahasan yang telah dikemukakan akhirnya dapat disimpulkan: (1) Potensi HKI dari hasil-hasil penilitian dan PPM para dosen UNY dalam kurun waktu tahun 2009-2011 masih rendah, yaitu hanya sebanyak 40 judul (18,89\%). Dari jumlah yang sedikit tersebut, ternyata sebagian besar temuan tersebut belum di-HKI-kan karena adanya berbagai alasan, seperti: belum mengetahui tata cara mendaftarkan HKI, belum bisa membuat draft paten, adanya beban biaya pendaftaran, dan biaya pemeliharaan paten yang mahal. (2) Upaya untuk meningkatkan perolehan HKI bagi civitas akademika UNY antara lain perlu dilakukan pelatihan maupun workshop yang dapat menjangkau semua peneliti dan pengabdi bilamana perlu bagi mahasiswa yang mendapatkan program PKM, sehingga akan makin banyak peneliti, pengabdi, pelaksana PKM yang memahami masalah HKI yang pada gilirannya akan mempunyai motivasi untuk mematenkan karyanya.

Saran bagi para peneliti dan pelaksana pengabdian, yaitu: (1) pada saat penyusunan proposal penelitian atau PPM sudah seharusnya terlintas untuk memikirkan produk penelitian atau PPM yang layak untuk dipatenkan, (2) pada saat pelaksanaan penelitian atau kegiatan PPM, temuan akhir kegiatan yang memungkinkan untuk dipatenkan perlu diupayakan dengan sebaikbaiknya sehingga memperoleh hasil yang maksimal dan layak untuk dipatenkan, dan (3) cermati berbagai aturan dan tata cara dalam usulan paten dan sesegera mungkin menyusun draft paten atas karyanya tersebut sebagai produk atau luaran dari hasil penelitian atau PPM-nya.

\section{DAFTAR PUSTAKA}

Undang-Undang Republik Indonesia. Nomor 19 Tahun 2002. Tentang Hak Cipta.

Asep Herman Suyanto. (2005). Peran Hak atas Kekayaan Intelektual (HKI) dalam Dunia Pendidikan. http://www.asep-hs. web.ugm.ac.id

A. Zen Umar Purba. (2001). Perlindungan dan Penegakan Hukum HKI. Direktur Jenderal Hak Kekayaan Intelektual Departemen KeHKIman dan Ham RI. Makassar. 20 November 2001.

LPPM UNY. (2011). RIP (Rencana Induk Penelitian) UNY tahun 2011

Kementrian Riset dan Teknologi. (2011). Pedoman Insentif Hak Kekayaan Intelektual.

Suryomurcito. (2003). Hak Atas Kekayaan Intelektual dan Lembaga Peradilan. Aktualita HKI. Januari 2003.

Universitas Negeri Yogyakarta. (2011). Laporan Tahunan Rektor Tahun 2011. Yogyakarta: UNY.

www. Webometrics.com 